\title{
Local and Global Spontaneous Calcium Events Regulate Neurite Outgrowth and Onset of GABAergic Phenotype during Neural Precursor Differentiation
}

\author{
Francesca Ciccolini, ${ }^{1,2}$ Tony J. Collins, ${ }^{1}$ Juliana Sudhoelter, ${ }^{1}$ Peter Lipp, ${ }^{1}$ Michael J. Berridge, ${ }^{1}$ and Martin D. Bootman ${ }^{1}$ \\ ${ }^{1}$ Laboratory of Molecular Signalling, The Babraham Institute, Babraham, Cambridge CB2 4AT, United Kingdom, and ${ }^{2}$ Cambridge Centre for Brain Repair, \\ Cambridge University, Forvie Site, Cambridge CB2 2PY, United Kingdom
}

Neural stem cells can generate in vitro progenitors of the three main cell lineages found in the CNS. The signaling pathways underlying the acquisition of differentiated phenotypes in these cells are poorly understood. Here we tested the hypothesis that $\mathrm{Ca}^{2+}$ signaling controls differentiation of neural precursors. We found low-frequency global and local $\mathrm{Ca}^{2+}$ transients occurring predominantly during early stages of differentiation. Spontaneous $\mathrm{Ca}^{2+}$ signals in individual precursors were not synchronized with $\mathrm{Ca}^{2+}$ transients in surrounding cells. Experimentally induced changes in the frequency of local $\mathrm{Ca}^{2+}$ signals and global $\mathrm{Ca}^{2+}$ rises correlated positively with neurite outgrowth and the onset of GABAergic neurotransmitter phenotype, respectively. NMDA receptor activity was critical for alterations in neuronal morphology but not for the timing of the acquisition of the neurotransmitter phenotype. Thus, spontaneous $\mathrm{Ca}^{2+}$ signals are an intrinsic property of differentiating neurosphere-derived precursors. Their frequency may specify neuronal morphology and acquisition of neurotransmitter phenotype.

Key words: neural precursors; neuronal differentiation; calcium signaling; neurospheres; NMDA receptors; GABA

\section{Introduction}

Neurons and glial cells, the main cell types of the mammalian CNS, arise from a common stem cell (for review, see McKay, 1997). Neural stem cells from embryonic or adult brain proliferate in vitro in response to epidermal growth factor (EGF) and fibroblast growth factor-2 (FGF-2) to produce clusters of cells termed neurospheres (Reynolds and Weiss, 1992; Ciccolini and Svendsen, 1998; Gritti et al., 1999; Ciccolini, 2002). In such in vitro conditions, neural stem cells self-renew and retain the ability to generate multiple cell types over long periods of time (Reynolds and Weiss, 1996). Thus, neurospheres represent an attractive and simplified system for studying how cell multiplicity and cell specification are achieved during mammalian neural development. In addition, neurosphere-derived precursors retain a stable karyotype, and numerous studies have indicated that cells derived from such cultures survive transplantation and, to some extent, can differentiate and form connections with cells of the host brain (Svendsen and Smith, 1999). Therefore, neurosphere cultures may have a clinical relevance representing a possible alternative to fetal tissue in the therapy of neurodegenerative diseases. However, progress toward the clinical use of such a system has been hampered by the limited yield of mature neurons obtained after transplantation of neurosphere-derived neural pre-

Received Jan. 9, 2002; revised Aug. 28, 2002; accepted Sept. 4, 2002.

This work was supported by the Biotechnology and Biological Sciences Research Council. M.D.B. gratefully acknowledges the support of a Royal Society Fellowship. F.C. gratefully acknowledges the support of a Merck Sharp and Dohme Fellowship.

Correspondence should be addressed to Dr. Martin D. Bootman, Laboratory of Molecular Signalling, The Babraham Institute, Babraham, Cambridge CB2 4AT, UK. E-mail: martin.bootman@bbsrc.ac.uk.

F. Ciccolini's present address: Department of Neurobiology, Interdisciplinary Center for Neurosciences, University of Heidelberg, Im Neuenheimer Feld 364, 69120 Heidelberg, Germany.

J. Sudhoelter's present address: Centre of Physiology, University of Goettingen, Goettingen, Germany. Copyright $\odot 2002$ Society for Neuroscience $\quad 0270-6474 / 02 / 220103-09 \$ 15.00 / 0$ cursors. This highlights the importance of investigating the mechanisms responsible for neuronal specification in this system.

Although many growth and neurotrophic factors can influence neuronal differentiation, several lines of evidence suggest that $\mathrm{Ca}^{2+}$ represents a key regulator of this process. Changes in the intracellular $\mathrm{Ca}^{2+}$ concentration as a result of spontaneous or signal-regulated events have been shown to initiate specific cellular programs that are important, for example, in differentiation of skeletal and heart muscle (Berridge et al., 1998). $\mathrm{Ca}^{2+}$ is a versatile intracellular messenger that can mediate divergent local and global responses in the same cell (Bootman et al., 2001). It is established that $\mathrm{Ca}^{2+}$ is a key regulator of cell specification in the developing nervous system. For example, in embryonic Xenopus spinal neurons, two types of spontaneous events have been characterized both in vitro and in vivo: fast-rising global $\mathrm{Ca}^{2+}$ spikes with characteristics of action potentials, and slower $\mathrm{Ca}^{2+}$ transients, termed waves, generated in the growth cone region (Gu et al., 1994). Information encoded in the frequency of $\mathrm{Ca}^{2+}$ spikes controls neurotransmitter expression and potassium channel maturation, whereas $\mathrm{Ca}^{2+}$ waves regulate neurite extension $(\mathrm{Gu}$ and Spitzer, 1995; Gomez and Spitzer, 1999). Some of these effects of $\mathrm{Ca}^{2+}$ are mediated by the regulation of the phosphorylation of structural proteins (Lautermilch and Spitzer, 2000); others, like the acquisition of neurotransmitter phenotype, may require gene transcription (Spitzer et al., 2000).

In the present study, we characterized spontaneous $\mathrm{Ca}^{2+}$ signals in differentiating neurosphere-derived precursors and their effects on specific aspects of neuronal morphology and differentiation. These data, together with the well established functions of spontaneous events identified in other experimental systems, suggest that specific $\mathrm{Ca}^{2+}$ signaling patterns play a key role in the differentiation of neural precursor cells. 


\section{Materials and Methods}

Culture of primary embryonic striatal cells. Striata from embryonic day 14 (E14) CD1 albino mouse embryos (plug day $=1.0$ ) (Charles River, Calco, Italy) were dissected and transferred into ice-cold culture medium consisting of DMEM/F12 (1:1) (Invitrogen, San Diego, CA; ICN Biochemicals, Cleveland, $\mathrm{OH}$ ), glucose $(0.6 \%)$, glutamine (2 mM), $\mathrm{NaHCO}_{3}$ (3 mM), HEPES buffer ( $5 \mathrm{~mm}$ ) (all from Sigma, St. Louis, MO), and 2\% B27 supplement (Invitrogen) (hereafter referred to as growth medium). The tissue was gently triturated with a fire-polished Pasteur pipette, and $10^{6}$ cells were plated at a density of $2 \times 10^{5}$ cells per milliliter in T25 Corning culture flasks in growth medium. EGF (Sigma) and FGF-2 (R \& D Systems, Minneapolis, MN) were added at a concentration of $20 \mathrm{ng} / \mathrm{ml}$ each. Half of the medium was replaced every $4 \mathrm{~d}$ with fresh medium containing the same concentration of growth factors.

Antibodies. The following antibodies were used at the indicated dilution: mouse monoclonal antibody to nestin (PharMingen; 1:1000 dilution); mouse monoclonal antibody to $\beta$ tubulin type III (TuJ1) (Sigma; 1:1000); rabbit polyclonal antibody to glial fibrillary acidic protein (GFAP) (Dako; 1:500); rabbit polyclonal antibody to GABA (Sigma; 1:500); mouse monoclonal antibody to galactocerebroside C (Gal-C) [kind gift of Dr. Neil Scolding (Bristol, UK); 1:10]; mouse monoclonal antibody to bromodeoxyuridine (BrdU) (Amersham; 1:100).

Differentiation of neurosphere-derived precursors. Neurospheres were rinsed in growth medium and mechanically triturated through a firepolished Pasteur pipette. Cells $\left(2 \times 10^{5}\right)$ were plated onto poly-L-lysinecoated coverslips in culture medium containing $1 \%$ fetal calf serum and FGF-2 $(2 \mathrm{ng} / \mathrm{ml})$ and returned to the incubator. Cells were left in differentiating conditions for up to $10 \mathrm{~d}$. The cell phenotype was determined immunocytochemically at different days after plating (DAP) using antibodies to TuJ1, nestin, and GFAP.

Cells were treated with various agents to either enhance or inhibit the $\mathrm{Ca}^{2+}$ signals. High $\mathrm{K}^{+}$treatment was achieved by adjusting the $\mathrm{KCl}$ concentration in the culture medium to $50 \mathrm{~mm}$. Low $\mathrm{Ca}^{2+}$ medium was obtained by replacing $\mathrm{CaCl}_{2}$ contained in the DMEM/F12 with $\mathrm{MgCl}_{2}$. For inhibition of NMDA receptors, APV (100 $\mu \mathrm{m}$; Sigma) was added to the medium.

Immunocytochemistry. Cells were fixed in $4 \%$ paraformaldehyde in PBS containing 4\% sucrose for $10 \mathrm{~min}$, rinsed several times in PBS, permeabilized in NP40 (0.5\% in PBS) for $5 \mathrm{~min}$, and blocked in goat serum (1.5\% in PBS) for $30 \mathrm{~min}$; all were performed at room temperature. After fixation, cells were incubated with primary antibodies overnight at $4^{\circ} \mathrm{C}$. GABA and BrdU were detected using biotin-conjugated secondary antibodies and Cy3-conjugated streptavidin (Vector Laboratories, Burlingame, CA). All other primary antibodies were detected using goat FITC-conjugated secondary antibodies (Vector). For BrdU staining, $\mathrm{BrdU}(10 \mu \mathrm{M})$ was added to differentiating neural precursors $1 \mathrm{~d}$ after plating. Twenty-four hours later, the cells were washed with culture medium and fixed in $100 \%$ ice-cold methanol at $-20^{\circ} \mathrm{C}$. After an additional $20 \mathrm{~min}$, the cells were washed in PBS once, exposed to $\mathrm{HCl}(2 \mathrm{M})$ for $20 \mathrm{~min}$ at $37^{\circ} \mathrm{C}$, and rinsed twice with Borate buffer $(0.1 \mathrm{M})$. Cells were incubated with $\mathrm{BrdU}$ antibody for $2 \mathrm{hr}$ at $37^{\circ} \mathrm{C}$ and then left overnight at $4^{\circ} \mathrm{C}$.

Neurite measurements and statistical analysis. At DAP 1, differentiating precursors were exposed to $\mathrm{KCl}(50 \mathrm{~mm})$, low $\mathrm{Ca}^{2+}$ conditions, or APV or left untreated (see Results). After $24 \mathrm{hr}$, cells were fixed, and the proportion of neurons in the culture was analyzed by immunocytochemistry using TuJ1 antibodies. The immunostained neurons were imaged with a Bio-Rad 1024 confocal microscope (Bio-Rad, Hemel Hempsted, UK). Photographs of isolated neurons in culture were taken, and the number of branches and the neurite length were measured using NIH Image. The means and SEs of at least three independent experiments were calculated, and statistical significance tests (ANOVA with post hoc Newman-Keuls) were performed using a statistical package (Graphpad Prism, San Diego, CA).

$\mathrm{Ca}^{2+}$ imaging. The cells were loaded with Fluo3 by incubation with 2 $\mu \mathrm{M}$ Fluo3-AM for $30 \mathrm{~min}$ at room temperature $\left(20-22^{\circ} \mathrm{C}\right)$ in an extracellular medium (EM) containing (in mM): $140 \mathrm{NaCl}, 3 \mathrm{KCl}, 1 \mathrm{MgCl}_{2}, 2$ $\mathrm{CaCl}_{2}, 10$ HEPES, 10 glucose. After loading with Fluo3-AM, the cells were washed with EM and incubated for a further 20 min to allow complete deesterification of the dye. $\mathrm{Ca}^{2+}$ imaging was performed with Noran $\mathrm{Oz}$ (Noran, Bicester, UK) and UltraView (PerkinElmer Life Sciences, Cambridge, UK) confocal microscopes, using image sizes of $256 \times 256$ pixels and acquisition rates of 0.5-7.5 frames per second. Fluo 3 was excited with a $488 \mathrm{~nm}$ line of an argon ion laser, and the emitted light $>505$ was detected. $\mathrm{Ca}^{2+}$ concentration was calculated from the Fluo3 fluorescence emission using a self-ratio equation as described previously (Cheng et al., 1993) assuming a $K_{\mathrm{d}}$ of $810 \mathrm{~nm}$ (Thomas et al., 2000). The $\mathrm{Ca}^{2+}$ imaging data in the present study were obtained at $20-22^{\circ} \mathrm{C}$.

Cell classification. In some experiments, imaged cells were classified as neurons or glial cells on the basis of morphological characteristics. Phasebright cells, with small oval cell bodies and one or two thin, not highly branched (typically not longer than two to three cell diameters) processes were considered as neurons. A representative picture of such neurons is given in the phase-contrast image in Figure 1 (top right image). The accuracy by which these criteria allow the identification of neurons was verified in a double-blind test in which cells at DAP 2 and 5 were fixed and immunostained with TuJ1 antibodies as described above. For each field, photographs were taken under illumination with both transmitted and fluorescent light. Cells were first scored as neuronal or glial according to the above-mentioned criteria; the exact identity of the cells was then assessed by examination of the corresponding immunofluorescence photograph. At DAP 2, none of the cells scored as neurons were immunopositive for Gal-C, and only a small fraction $(\sim 1 \%)$ were identified as GFAP-immunoreactive astrocytes. The majority of the cells $(\sim 60 \%)$ scored as neurons were TuJ1 positive; $\sim 30-40 \%$ were nestin positive and thus are likely to be immature (not yet TuJ1 positive) neuronal precursors. At DAP 5, $>90 \%$ of the cells classified as neurons stained for $\mathrm{TuJ} 1$, consistent with the expression of this marker as the cells matured.

Categorizing $\mathrm{Ca}^{2+}$ transients. $\mathrm{Ca}^{2+}$ transients were classified as global when the fluorescence increased in the whole cell body. Localized $\mathrm{Ca}^{2+}$ transients refer to spatially restricted $\mathrm{Ca}^{2+}$ increases with amplitudes that were three times greater than the SD of the baseline noise. Throughout this study, localized $\mathrm{Ca}^{2+}$ events were analyzed only in cells with neuronal morphology.

\section{Results \\ Spontaneous $\mathrm{Ca}^{2+}$ events during neural precursor differentiation: global and localized transients}

Neurosphere cultures were obtained by growing in vitro E14 mouse striatal cells in the presence of both EGF and FGF-2. At the E14 stage, the vast majority of neurosphere-derived cells are undifferentiated (Ciccolini and Svendsen, 1998) and express nestin, a cytoskeleton protein found mainly in neural precursors (Lendahl et al., 1990). During plating onto a substrate, neurospherederived precursors differentiate into both glial and neuronal cells. Two days after plating, the majority of the cells expressed both nestin and the astrocytic marker GFAP (Fig. 1), whereas cells expressing TuJ 1 were few at DAP $2(2.77 \pm 0.65 \%)$. The percentage of neurons increased between DAP 3 and 6 to $16.8 \pm 4.1 \%$ (Fig. 1), whereas the total number of cells did not change (data not shown). At DAP 2, the majority of TuJ1-immunoreactive cells did not express nestin or GABA (Fig. 1), whereas by DAP 6, GABA neurotransmitter was expressed in virtually all neurons (Fig. 1). These results indicate that in our system neurospherederived precursors undergo differentiation between DAP 1 and DAP 6, as indicated by downregulation of nestin expression. Neurogenesis occurs mainly between DAP 2 and 6 when expression of GABA is detected in all neurons.

We investigated whether spontaneous $\mathrm{Ca}^{2+}$ transients occurred during neural precursor differentiation. DAP 1 neurospherederived precursor cells were loaded with Fluo3, and $\mathrm{Ca}^{2+}$ transients were recorded for $30 \mathrm{~min}$ with a confocal microscope. In addition, neural precursors were defined as glial or neuronal cells on the basis of morphological criteria (see Material and 


\section{DAP2}
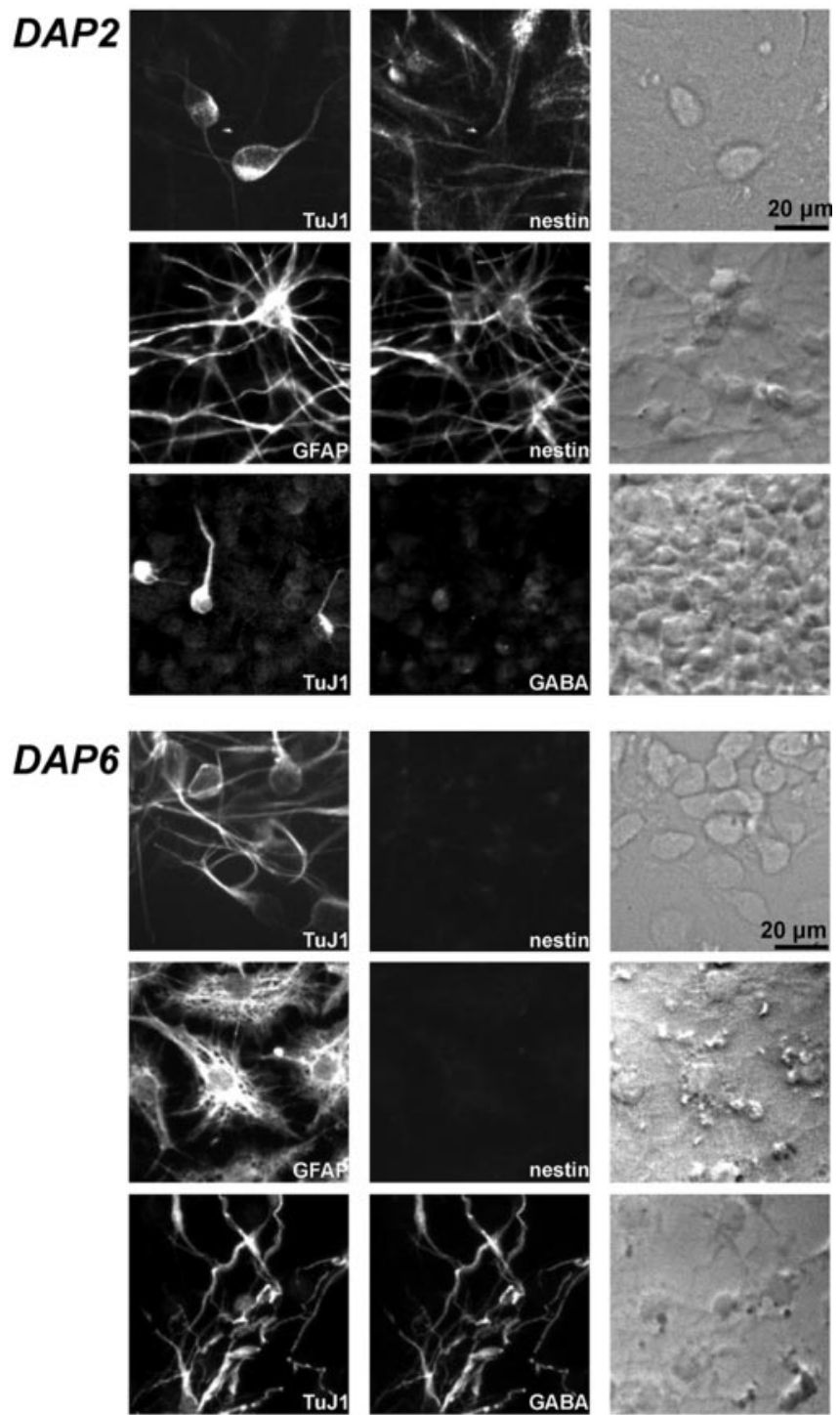

Figure 1. Expression of differentiation markers in cultured neurosphere-derived precursors. The panels show examples of double immunostaining identifying neurons (TuJ1 immunoreactive) and nestin-immunoreactive precursors (top row), astrocytes (GFAP immunoreactive) and precursors (middle row), and neurons and GABA-immunopositive cells (bottom row) in neurosphere-derived cultures grown for $7 \mathrm{~d}$ in the presence of EGF and FGF- 2 and differentiated for an additional $2 \mathrm{~d}(D A P 2)$ and $6 \mathrm{~d}$ (DAP 6). Phase-contrast photographs of each field are shown in the right-hand column.

Methods for a detailed description). Spontaneous $\mathrm{Ca}^{2+}$ signals were observed in both glial and neuronal cells. Two main types of spontaneous $\mathrm{Ca}^{2+}$ events were found in differentiating precursors: global $\mathrm{Ca}^{2+}$ transients, which engulfed the whole cell body, and localized events, in which $\mathrm{Ca}^{2+}$ increases were limited to a subcellular region, usually a process (Fig. 2). Global events were characterized by a sudden (generally lasting $<3 \mathrm{~min}$ ) and conspicuous increase of the intracellular $\mathrm{Ca}^{2+}$ concentration (Fig. 2, regions 4 and 6) or irregular and smaller increases of the intracellular $\mathrm{Ca}^{2+}$ concentration (often $<200 \mathrm{~nm}$ ). The local $\mathrm{Ca}^{2+}$ signals were of variable amplitude and duration. Although they occurred occasionally in cell bodies (Fig. 2, region 2), they were most often observed in cellular processes (Fig. 2, regions 3 and 5). Similar types of spontaneous $\mathrm{Ca}^{2+}$ signals were found when cells were imaged either at room temperature or at $37^{\circ} \mathrm{C}$ (data not shown).
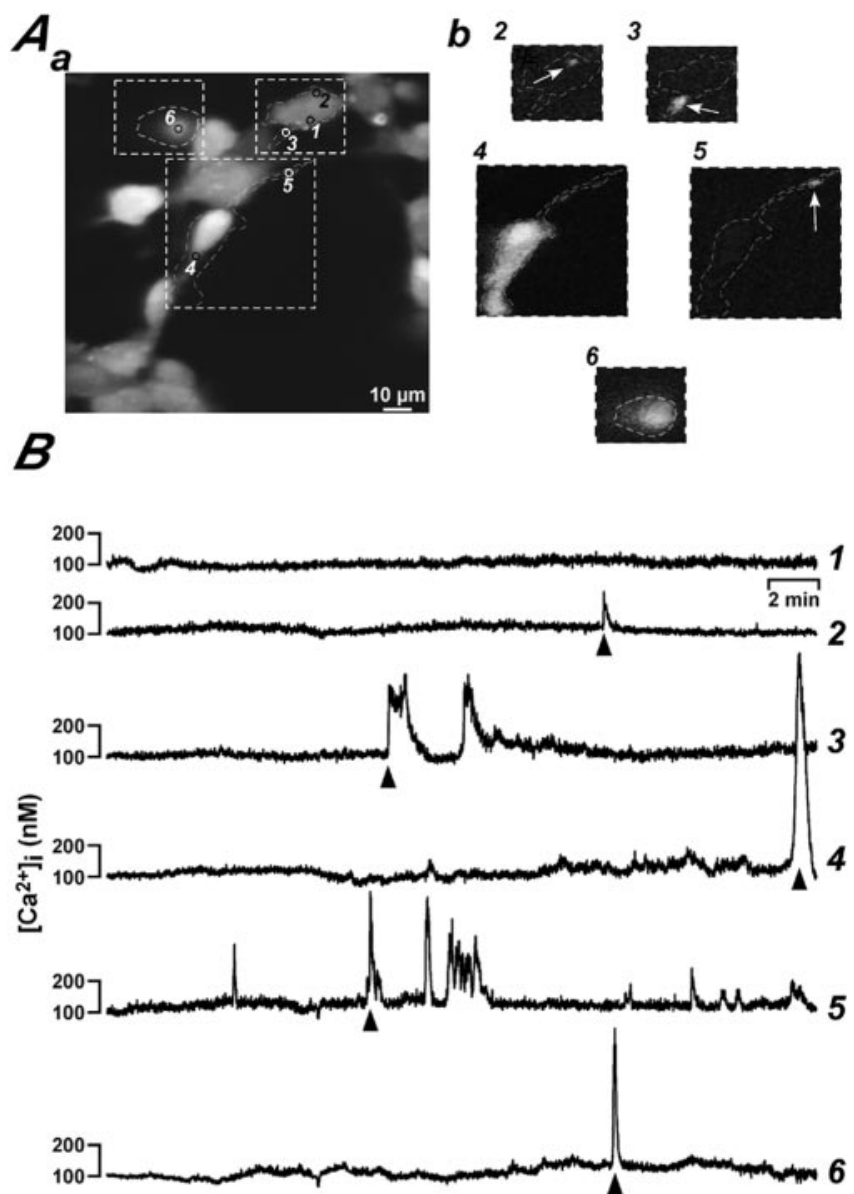

Figure 2. Examples of spontaneous local and global $\mathrm{Ca}^{2+}$ signals in neurosphere-derived precursors $1 \mathrm{~d}$ after induction of differentiation. Aa, Confocal image showing a field of cells loaded with Flu03. The numbered circles indicate the subcellular regions from which $\mathrm{Ca}^{2+}$ changes were analyzed. Examples of the observed local and global $\mathrm{Ca}^{2+}$ signals are depicted in $A b$. The traces in $B$ show the time course of calcium signals from the correspondingly numbered regions in $A a$. The arrowheads beneath the traces in $B$ indicate the particular $\mathrm{Ca}^{2+}$ signals shown in $A b$.

We next characterized global and local $\mathrm{Ca}^{2+}$ events at different days after plating to investigate whether their properties were modified during neural precursor differentiation. Neurospherederived precursors were imaged for $10 \mathrm{~min}$ at room temperature $3 \mathrm{hr}$ after induction of differentiation (DAP 0) and at DAP 1, 2, and 5 (i.e., 24, 48, and $120 \mathrm{hr}$ after differentiation was induced). For each day, we noted the number of spontaneously active cells in addition to the characteristics of the global and local $\mathrm{Ca}^{2+}$ signals. We observed that the percentage of cells displaying global $\mathrm{Ca}^{2+}$ signals peaked between DAP 1 and 2 and then declined (Fig. $3 A$ ). The frequencies of the global signals reduced (Fig. $3 B$ ), and their amplitudes showed a significant increase (Fig. $3 \mathrm{C}$ ) as the cells differentiated.

The local $\mathrm{Ca}^{2+}$ signals were analyzed from DAP 1, by which time the cells had already extended processes. As in the case of global $\mathrm{Ca}^{2+}$ signals, we found that the percentage of cells displaying local $\mathrm{Ca}^{2+}$ transients and the frequency of such events were greater during the first $2 \mathrm{~d}$ of development (Fig. $3 A, B$ ). The amplitude of local $\mathrm{Ca}^{2+}$ signals did not alter significantly. The overall pattern from these data is that both the global and local spontaneous $\mathrm{Ca}^{2+}$ signals were observed more frequently at early stages of neural precursor differentiation.

Throughout the study, the local $\mathrm{Ca}^{2+}$ events were analyzed 


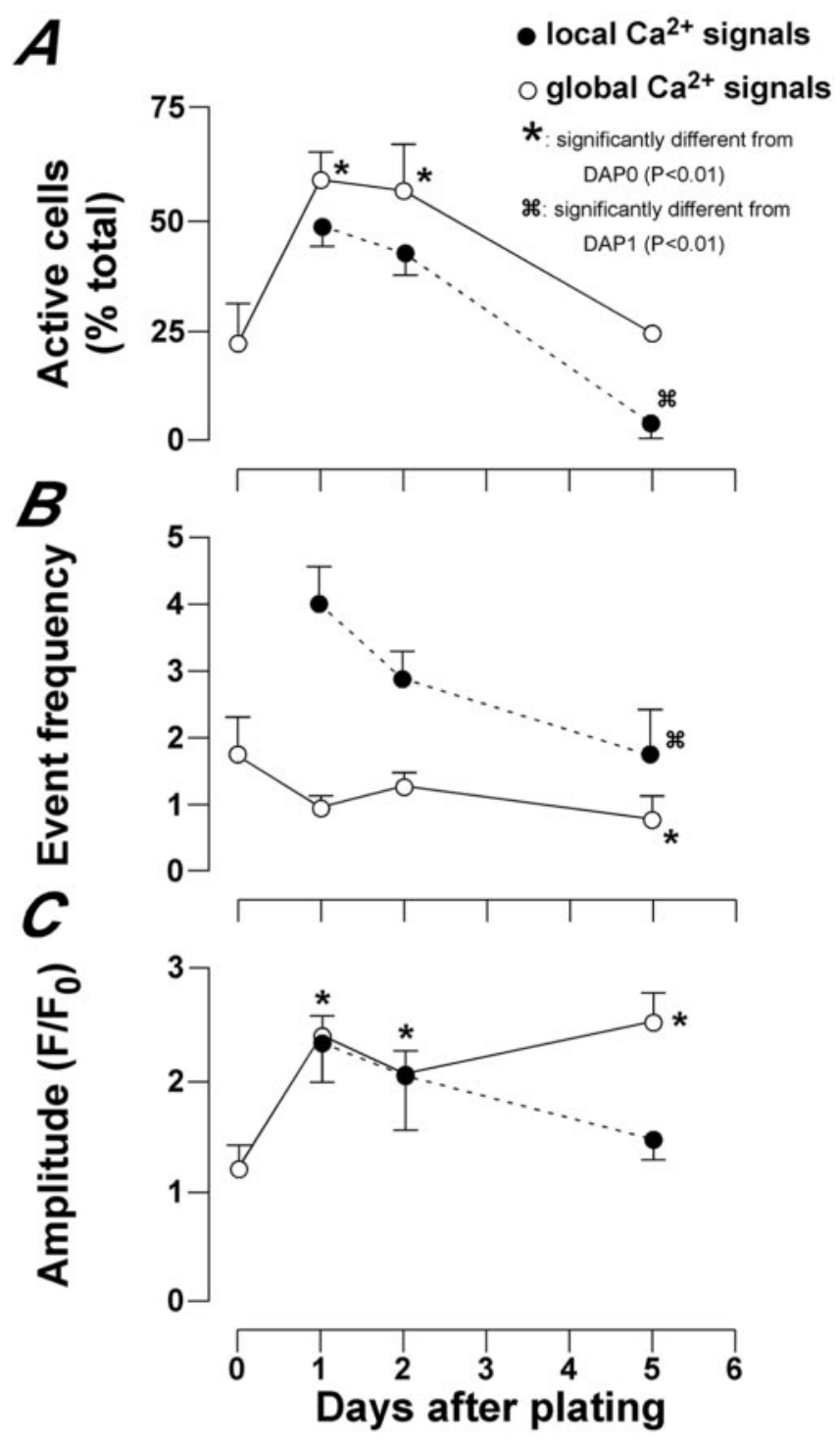

Figure 3. The occurrence of both global and local events decreases during differentiation. The graphs indicate the number of active cells $(A)$, the frequency of events (number of events per cell or branch during a 10 min recording) $(B)$, and the amplitude of the $\mathrm{Ca}^{2+}$ signals for both global and local responses after induction of differentiation (C). Please note that the local $\mathrm{Ca}^{2+}$ responses were measured from cells with neuronal morphology only. The global responses reflect glial and neuronal signals pooled, to show the decline of $\mathrm{Ca}^{2+}$ transients throughout the culture. The data represent the mean \pm SEM of at least three independent experiments with an average of 69 cells analyzed for each time point.

only in neuronal cells; however, we did examine the activity of global $\mathrm{Ca}^{2+}$ signals in both neuronal and glial cells. The data presented in Figure 3 showing that global $\mathrm{Ca}^{2+}$ signaling declined in all the cells reflect the pooled activities of the glial and neuronal cells. When global events were analyzed separately in glial and neuronal cells, we found that the spontaneous global $\mathrm{Ca}^{2+}$ signals declined almost in parallel in the two cell populations. The only significant difference between these cell types was observed at DAP 5 when $24.7 \pm 8.5 \%$ of glial cells and $5 \pm 5 \%$ of neurons were showing spontaneous global calcium signals.

We examined whether changes in the expression of functional channels and receptors involved in generating $\mathrm{Ca}^{2+}$ signals were responsible for the decline in spontaneous events. The response of neuronal and glial cells to depolarization with $\mathrm{KCl}(60 \mathrm{~mm})$, caffeine $(40 \mathrm{mM})$, and glutamate $(100 \mu \mathrm{M})$ was tested at various days after induction of differentiation. Depolarization using $\mathrm{KCl}$ evoked acute $\mathrm{Ca}^{2+}$ signals in almost all identified neurons and the majority of glial cells at all stages of differentiation (Fig. 4A). The amplitude of the $\mathrm{KCl}$-induced $\mathrm{Ca}^{2+}$ signals in glial cells did not alter appreciably, whereas the response of the neurons increased substantially from DAP 1 to DAP 8, and then rose dramatically at DAP 10. Caffeine, on the other hand, evoked similar amplitude $\mathrm{Ca}^{2+}$ signals at all stages, with little difference between neurons and glial cells (Fig. $4 \mathrm{~B}$ ). However, caffeine was the most unreliable agonist in that the proportion of responsive cells varied considerably between days, and many cells failed to respond (Fig. $4 B, c$ ). The effect of glutamate was also rather variable, but there was a clear trend for an increasing number of neurons to be glutamate responsive with time in culture (Fig. 4C). In summary, the neurons seem to become increasingly competent at $\mathrm{Ca}^{2+}$ signaling as differentiation proceeds. Therefore, the loss of spontaneous $\mathrm{Ca}^{2+}$ signals is not attributable to the neurons lacking the ability to generate $\mathrm{Ca}^{2+}$ signals, but rather results from the incidence of spontaneous events declining as the neurons and glial cells mature.

Modulating the frequency of spontaneous $\mathrm{Ca}^{2+}$ events The observation that the frequency and the number of spontaneous events peaked at early stages of neural precursor differentiation, when neurogenesis occurs, prompted us to investigate whether spontaneous $\mathrm{Ca}^{2+}$ signaling plays a role in neuronal specification. To investigate this hypothesis, we manipulated the culture conditions during neural precursor differentiation to interfere with $\mathrm{Ca}^{2+}$ signaling.

The origin of spontaneous $\mathrm{Ca}^{2+}$ events in differentiating neural precursors is still an object of discussion. In amphibian spinal neurons, it has been proposed that some spontaneous events originate from $\mathrm{Ca}^{2+}$ entry through voltage-dependent $\mathrm{Ca}^{2+}$ channels and that $\mathrm{Ca}^{2+}$ release from intracellular stores contributes to their amplitude ( $\mathrm{Gu}$ et al., 1994). Therefore, we examined the effect of modulating $\mathrm{Ca}^{2+}$ entry on spontaneous $\mathrm{Ca}^{2+}$ events.

After dissociation, neurosphere-derived cells were plated on poly-L-lysine-coated coverslips in differentiating conditions as described above. On DAP 1, the cells were exposed to three different conditions: low extracellular $\mathrm{Ca}^{2+}(\sim 100 \mu \mathrm{M}), 50 \mathrm{mM}$ $\mathrm{KCl}$, or untreated (control). During the course of this study, the various treatments were always applied $24 \mathrm{hr}$ after the initial plating on coverslips so that there was no interference with the cells before they were fully adhered.

We found that incubation in low extracellular $\mathrm{Ca}^{2+}$ medium (for $\geq 24 \mathrm{hr}$ ) completely inhibited the occurrence of all types of spontaneous $\mathrm{Ca}^{2+}$ signal from DAP 2 onward (data not shown). In contrast, the control and $\mathrm{KCl}$-treated cells continued to display spontaneous $\mathrm{Ca}^{2+}$ events. The effect of $\mathrm{KCl}$ treatment was to enhance the propensity of the cells to show spontaneous local and global $\mathrm{Ca}^{2+}$ signals at all stages of differentiation. For global signals, this was evident most significantly in the frequency of events (Fig. 5A, $a$ ) and the amplitude of the signals (Fig. 5A, $b$ ) at various stages. The proportion of active cells at DAP 5 was also enhanced by $\mathrm{KCl}$ (Fig. $5 A, c$ ), but this was caused primarily by the activity of cells with astrocytic morphology (Fig. $5 B, C$ ). Although depolarization increased the frequency and amplitude of global $\mathrm{Ca}^{2+}$ signals, it did not prevent the trend that the neurons within the culture became increasingly quiescent with respect to global $\mathrm{Ca}^{2+}$ signals. The number of active neurons declined even in the presence of $\mathrm{KCl}$ (Fig. $5 B$ ). The sustained effect of $\mathrm{KCl}$ on the frequency of events (Fig. $5 A, a$ ) was caused by the activity of glial cells. 
A
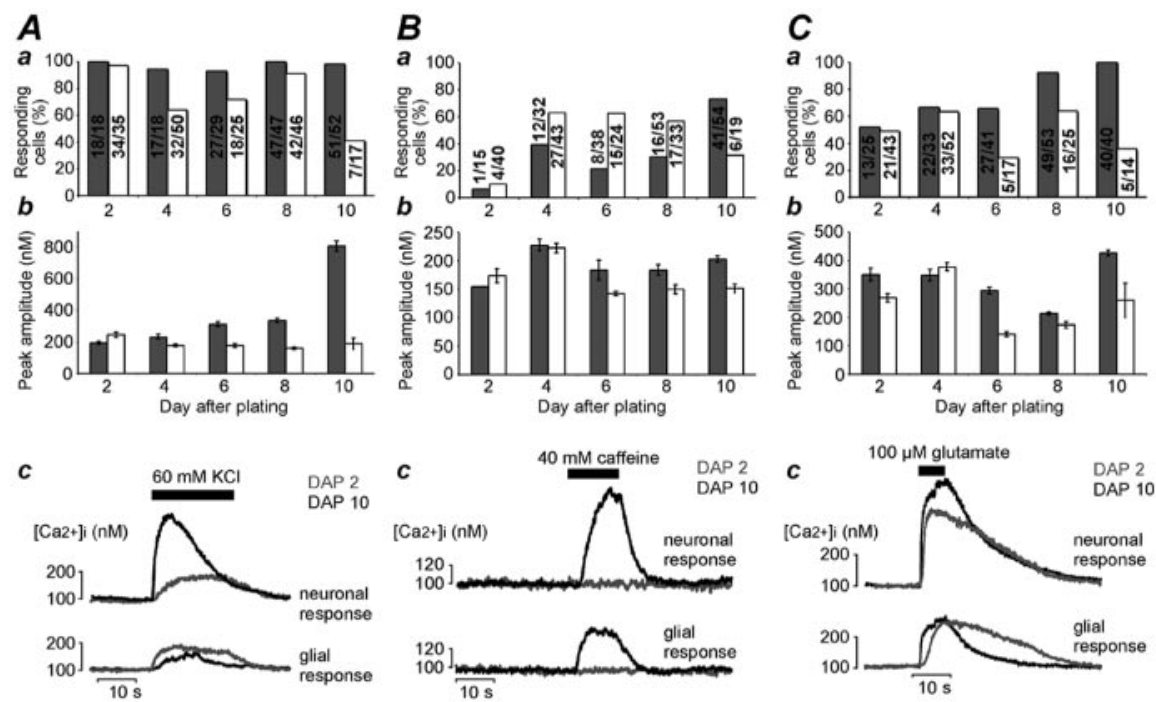

Figure 4. Changes in $\mathrm{Ca}^{2+}$ signaling capacity of differentiating neurons and glial cells. $A-C$ indicate responses of neuronal (gray bars) and glial cells (white bars) to acute stimulation with $\mathrm{KCl}(A)$, caffeine $(B)$, and glutamate $(C)$. Mean \pm SEM data are shown in $A a-C b$. The numbers on the bars in $A a, B a$, and $C a$ indicate the fraction of responsive cells, with the denominator indicating the number of cells analyzed. The peak amplitude data were calculated using responsive cells only. The traces in $A c-C c$ show examples of the responses of single neuronal and glial cells at the earliest (DAP 2) and latest (DAP 10) time points tested. The traces were chosen randomly from matched experiments.
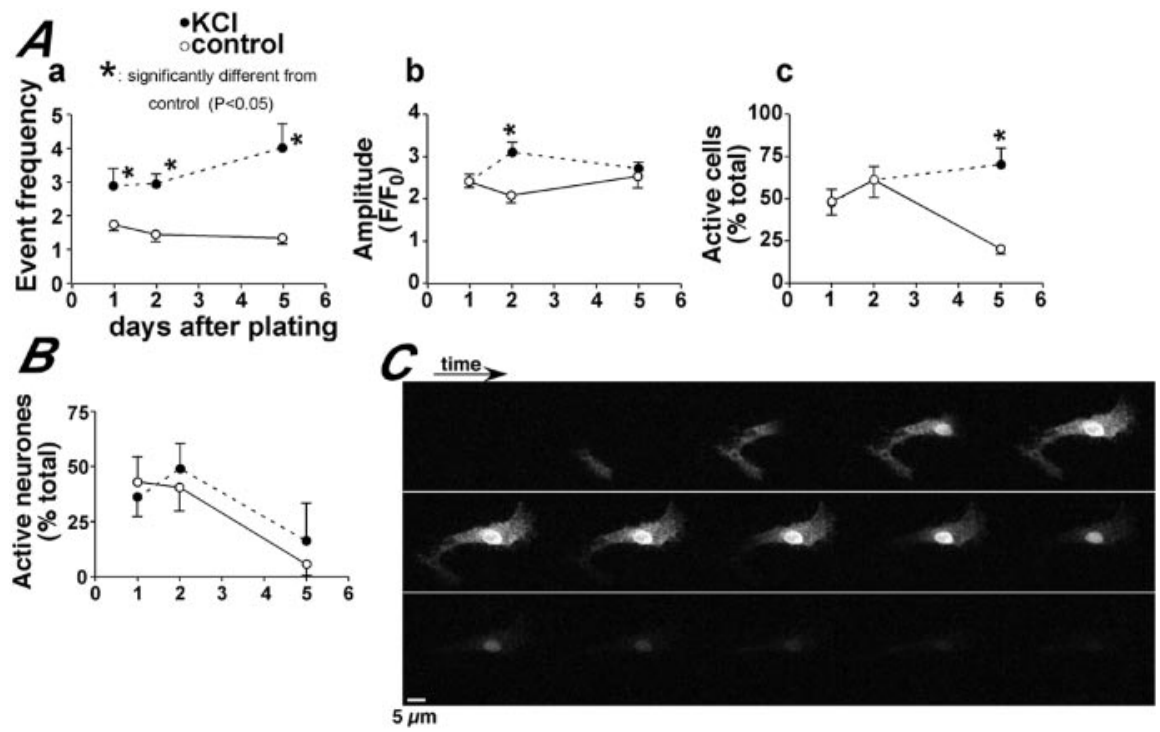

Figure 5. Membrane depolarization enhances global $\mathrm{Ca}^{2+}$ signals. $A a-A c$ illustrate the effect of $50 \mathrm{~mm} \mathrm{KCl}$ on the characteristics of global $\mathrm{Ca}^{2+}$ signals at different days after induction of differentiation. Event frequency $(A a)$ indicates the number of events per cell or branch during a 10 min recording. The graph in B illustrates that the number of neurons showing global $\mathrm{Ca}^{2+}$ signals declined with or without $\mathrm{KCl}$ treatment. The data shown represent the mean \pm SEM of at least three independent experiments in which an average of 154 cells were analyzed for each time point. The images in Cillustrate an example of a global $\mathrm{Ca}^{2+}$ signal in a cell with astrocytic morphology at DAP 5 . Images of the same cell are shown at 15 sec intervals, with time running from left to right and top to bottom.

$\mathrm{KCl}$ had an even greater effect in enhancing the propensity of the neuronal cells to show local $\mathrm{Ca}^{2+}$ signals. This effect was observed in terms of proportion of active cells (Fig. 6A), frequency of local $\mathrm{Ca}^{2+}$ signals (Fig. $6 \mathrm{~B}$ ), and event amplitude (Fig. $6 C$ ). These data indicate that multiple aspects of the local and global $\mathrm{Ca}^{2+}$ signals in the cells acquiring neuronal phenotype could be upregulated using $\mathrm{KCl}$.
The enhancement of local, but not global, $\mathrm{Ca}^{2+}$ signals by $\mathrm{KCl}$ was dependent on NMDA receptor activity. In DAP 1 cells, application of $\mathrm{KCl}$ increased the occurrence of local $\mathrm{Ca}^{2+}$ signals from control values of $3.9 \pm 0.9$ to $12.2 \pm 1.6$ events per branch during a 10 min recording (data from at least 15 branches). The NMDA receptor antagonist APV applied together with $\mathrm{KCl}$ reduced the incidence of local $\mathrm{Ca}^{2+}$ transients back to control levels ( $5 \pm 0.9$ events per branch; data from 18 branches). APV had no effect on the occurrence of global signals. In addition, APV did not alter the generation of local or global $\mathrm{Ca}^{2+}$ signals when applied in the absence of $\mathrm{KCl}$ (data not shown). In control conditions, the majority ( $>75 \%)$ of local $\mathrm{Ca}^{2+}$ signals occurred preferentially at the most distal region of a neurite. When cells were exposed to $\mathrm{KCl}$, the $\mathrm{Ca}^{2+}$ signals still originated preferentially in distal neuritic regions, but they were also detectable in more proximalregions because of a greater spreading of the events (data not shown). Therefore, depolarization not only promoted the frequency and amplitude of local $\mathrm{Ca}^{2+}$ signals, but it also increased their spatial extent. The enhanced spreading of the local $\mathrm{Ca}^{2+}$ signals was also dependent on NMDA receptor activity. In control and $\mathrm{KCl}+\mathrm{APV}$ conditions, the average spreading of local $\mathrm{Ca}^{2+}$ signals was $3.2 \pm 0.3$ and $2.7 \pm 0.2$ $\mu \mathrm{m}$, respectively. In contrast, in the presence of $\mathrm{KCl}$ alone, the average length of each event was $5.8 \pm 0.4 \mu \mathrm{m}$.

The frequency of spontaneous $\mathrm{Ca}^{2+}$ signals correlates with acquisition of neurotransmitter phenotype and neurite length

By differentiating the precursor cells in the conditions described above, we were able to either inhibit (low $\mathrm{Ca}^{2+}$ medium) or enhance $(\mathrm{KCl})$ the spontaneous $\mathrm{Ca}^{2+}$ signals relative to control conditions. We therefore used these experimental conditions to examine the effect of spontaneous $\mathrm{Ca}^{2+}$ signals on the development of neuronal morphology and neurotransmitter phenotype.

Importantly, $24 \mathrm{hr}$ exposure to these treatments did not cause a change in the rate of neural precursor proliferation or survival. To investigate the effect of the various treatments on cell proliferation, we first analyzed the number of dividing cells in control, $\mathrm{KCl}$, and low calcium-treated cultures. At DAP 2, after $24 \mathrm{hr}$ of differentiation in the presence of $\mathrm{BrdU}$, we found similar BrdU incorporation rates across the different conditions (Table 1), indicating that the modification of neuronal phenotypes observed was not caused by a change in neural progenitor proliferation. To rule out the possibility that 


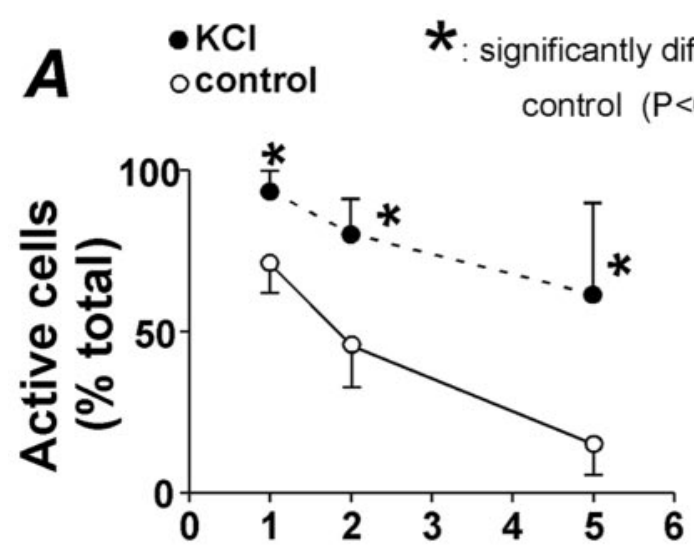

$B$
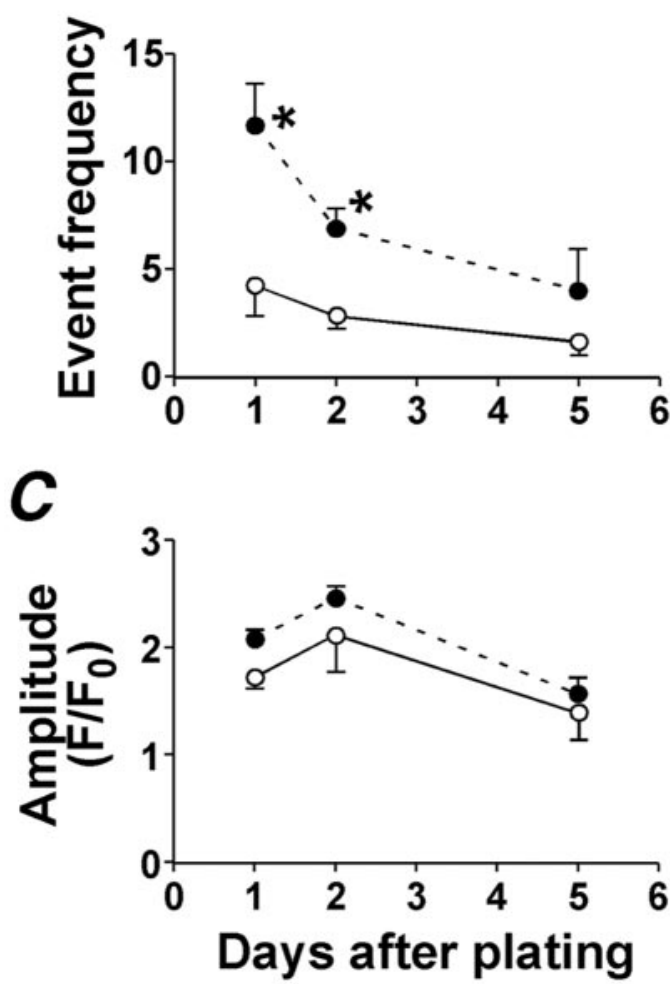

Figure 6. Membrane depolarization enhances local $\mathrm{Ca}^{2+}$ signals. A-Cillustrate the effect of $50 \mathrm{~mm} \mathrm{KCl}$ on the characteristics of local $\mathrm{Ca}^{2+}$ signals at different days after induction of differentiation. Event frequency $(B)$ indicates the number of local $\mathrm{Ca}^{2+}$ signals observed during a 10 min recording. The data shown represent the mean \pm SEM of at least three independent experiments in which an average of 76 cells were analyzed for each time point.

the applied treatments specifically affected the proliferation of neurons, we analyzed the cell division of neurons during the exposure to the different conditions by examining TuJ1 and BrdU costaining. These data demonstrate that only $\sim 4 \%$ of the neuronal population had divided during the $24 \mathrm{hr}$ exposure to the different conditions and that $\mathrm{KCl}$ or low calcium treatments did not cause a significant variation in the number of BrdUimmunopositive neurons compared with control conditions (Table 1). Throughout the study we used TuJ1 to identify neurons. Because TuJ1 is a neuronal marker expressed in postmitotic cells, our data also show that most of the neurons ( $\sim 96 \%)$ found at DAP 2 exited the cell cycle before being exposed to the various treatments.

To investigate the possibility that the different conditions
Table 1. Effect of $\mathrm{KCl}(50 \mathrm{~mm})$ and low $\mathrm{Ca}^{2+}$ treatments on cell proliferation and death in the neuronal precursor cultures

\begin{tabular}{lrrr}
\hline & Control & $\mathrm{KCl} 50 \mathrm{~mm}$ & Low $\mathrm{Ca}^{2+}$ \\
\hline $\begin{array}{l}\text { Cells staining with TuJ1, i.e., } \\
\text { proportion of neurons in } \\
\text { the culture (5) }\end{array}$ & $3.7 \pm 0.9$ & $3.2 \pm 0.6$ & $2.4 \pm 0.1$ \\
$\begin{array}{l}\text { Cells that incorporated } \\
\text { BrdU (5) }\end{array}$ & $20.5 \pm 6.2$ & $23.4 \pm 7.9$ & $15 \pm 6.3$ \\
$\begin{array}{l}\text { Neurons that incorporated } \\
\text { BrdU (4) }\end{array}$ & $3.3 \pm 1.1$ & $4 \pm 0.7$ & $5.2 \pm 0.8$ \\
$\begin{array}{l}\text { Cells staining with DAPI (4) } \\
\text { Cells displaying pyknotic } \\
\text { nuclei (3) }\end{array}$ & $7.7 \pm 1.6$ & $10.5 \pm 1.9$ & $7.6 \pm 1.5$ \\
\hline
\end{tabular}

The table shows the percentage of cells staining with the markers described in the left-most column or showing pyknotic nuclei. Neurosphere-derived precursors were plated onto poly-L-lysine-coated coverslips. The indicated treatments and BrdU were added $24 \mathrm{hr}$ after plating. Cells were analysed after an additional 24 hours. The values represent the means \pm SEM. The values in parentheses indicate the number of experiments. For each experiment at least two fields of cells, each containing on average 80 cells, were analysed. DAPI and Hoechst concentration were used at concentrations of $1 \mathrm{mg} / \mathrm{ml}$. DAPI was added to live cells $5-10$ min beforescoring the coverslips. Hoechstwas added to fixed cells and left for $40-60$ min.

might affect cell death, we analyzed whether cell viability varied across the different conditions by dye (DAPI) exclusion. In addition, we investigated the number of pyknotic nuclei found in control cultures and in cultures exposed to $\mathrm{KCl}$ or low calcium for $24 \mathrm{hr}$. Both assays revealed no significant change in cell death across the different conditions (Table 1). Together with the observations that neuronal and total cell numbers are not affected by the various treatments, these data demonstrate that the eventual changes in neuronal phenotype observed after interfering with calcium signals are caused by calcium modulation of neuronal differentiation rather than changes in survival or proliferation rates.

When control and KCl-treated cultures were analyzed at DAP 5 , we found that most of the neurons were GABA immunoreactive in either condition (Fig. 7). However, at DAP 2 the number of GABA-expressing cells increased significantly after $\mathrm{KCl}$ treatment, both in the presence and in the absence of APV, and decreased to almost negligible levels after exposure to low $\mathrm{Ca}^{2+}$ medium (Fig. 8). At DAP 2, there was no significant difference in the proportion of neurons (identified by $\mathrm{TuJ} 1$ expression) found in control and treated cultures. These data indicate that enhancing global $\mathrm{Ca}^{2+}$ signaling did not influence the type of neurotransmitter phenotype acquired during neural precursor differentiation. However, increasing the frequency of the global $\mathrm{Ca}^{2+}$ signals accelerated the acquisition of GABAergic phenotype.

We next investigated whether $\mathrm{Ca}^{2+}$ signals affected neuronal morphology. Cultures differentiating in the presence of low $\mathrm{Ca}^{2+}, \mathrm{KCl}, \mathrm{KCL}+\mathrm{APV}$, and control conditions were fixed at DAP 2. The neurons were identified by TuJ1 immunostaining. The number of branch points and the lengths of neurites were measured on neurons found in fields of comparable cell density. Differentiation of cells in the low $\mathrm{Ca}^{2+}$ conditions significantly decreased the neurite length, compared with control cultures (Fig. $9 A, B$ ). In contrast, the neuronal processes were significantly longer in $\mathrm{KCl}$-treated cultures than in control (Fig. 9). The KClinduced change in neuronal morphology was mediated by NMDA receptor activation. As illustrated in Figure 9C, the presence of the NMDA receptor blocker APV abolished the effect of $\mathrm{KCl}$ on neurite length. A similar pattern was observed when cells were analyzed after a $4 \mathrm{~d}$ exposure to the different treatments. The neurites of KCl-treated DAP 5 cells were $260 \pm 34 \%$ longer than DAP 5 neurons grown in control conditions. Therefore, the effects of altering the frequency of spontaneous $\mathrm{Ca}^{2+}$ signals on 


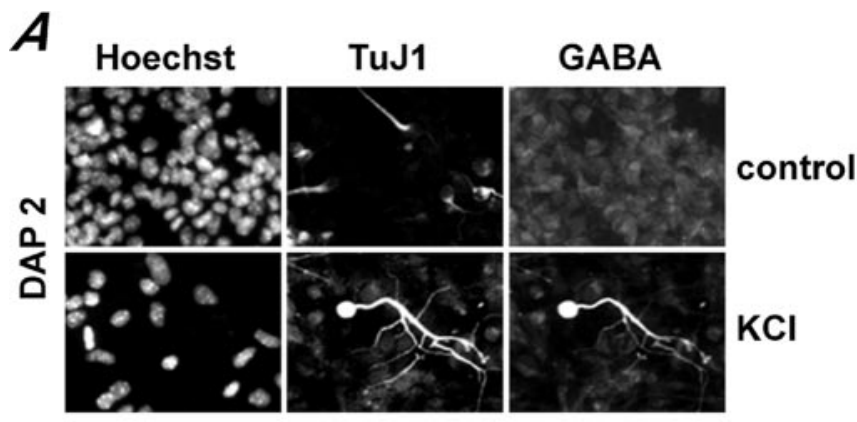

$\boldsymbol{B}$

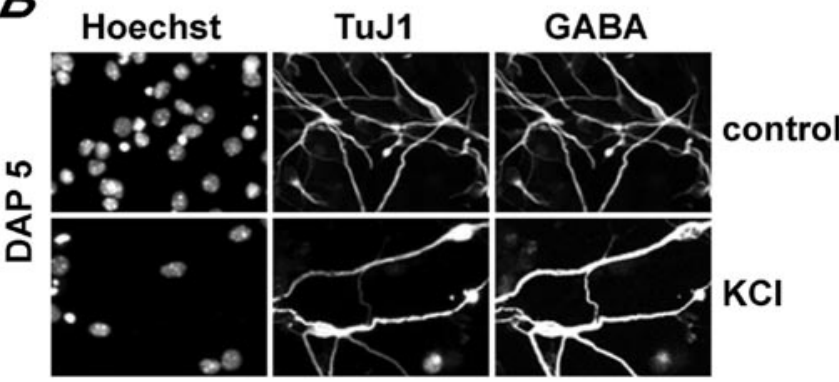

Figure 7. Effect of $\mathrm{KCl}$ treatment on $\mathrm{GABA}$ expression. Neurosphere-derived neurons were analyzed for TuJ1 and GABA expression at $2 \mathrm{~d}(A, D A P 2)$ and $5 \mathrm{~d}(B, D A P 5)$ after induction of differentiation. The Hoechst fluorescence is shown to indicate the position of the cell nuclei.

neurite morphology were rapidly initiated in the differentiating cells and maintained as the cells matured.

These data indicate that the frequency of local $\mathrm{Ca}^{2+}$ signals correlated with neurite extension and neurite branching. Changes in neurite morphology, but not acquisition of neurotransmitter phenotype, required NMDA receptor activation.

\section{Discussion}

In this study, we show that spontaneous $\mathrm{Ca}^{2+}$ signaling is an intrinsic characteristic of differentiating neurosphere-derived precursors. We used two different methods of altering the occurrence of spontaneous $\mathrm{Ca}^{2+}$ signals to examine their effect on neuronal development. Our results indicate that $\mathrm{Ca}^{2+}$ signaling is a mediator of neural precursor differentiation and may regulate the maturation of the neuronal phenotype. Because $\mathrm{Ca}^{2+}$ is a ubiquitous second messenger, these observations may indicate that modulation of the intracellular $\mathrm{Ca}^{2+}$ concentration represents a common target for factors and signals that regulate neural precursor differentiation.

Spontaneous $\mathrm{Ca}^{2+}$ oscillations occur in many different neuronal types and at different stages of maturation (Sorimachi et al., 1990; Yuste et al., 1992; Wong et al., 1995; Owens et al., 2000; Liljelund et al., 2000). They have been implicated in the regulation of several aspects of neuronal differentiation such as migration (Komuro and Rakic, 1996), neuronal wiring (Feller et al., 1996), and neuronal differentiation (Gomez et al., 1995; Gu and Spitzer, 1995; Carey and Matsumoto, 1999). Consistent with a role in the acquisition of neuronal phenotype, we found that in our system spontaneous $\mathrm{Ca}^{2+}$ signals were frequent at early stages of differentiation (i.e., DAP 2) (Figs. 2, 6). In addition, interference with $\mathrm{Ca}^{2+}$ signaling at this early stage correlated with changes in the neuronal morphology and neurotransmitter expression (Figs. 7-9). In developing amphibian neurons, these two particular aspects of neuronal differentiation are regulated by the frequency and the site of generation of spontaneous $\mathrm{Ca}^{2+}$
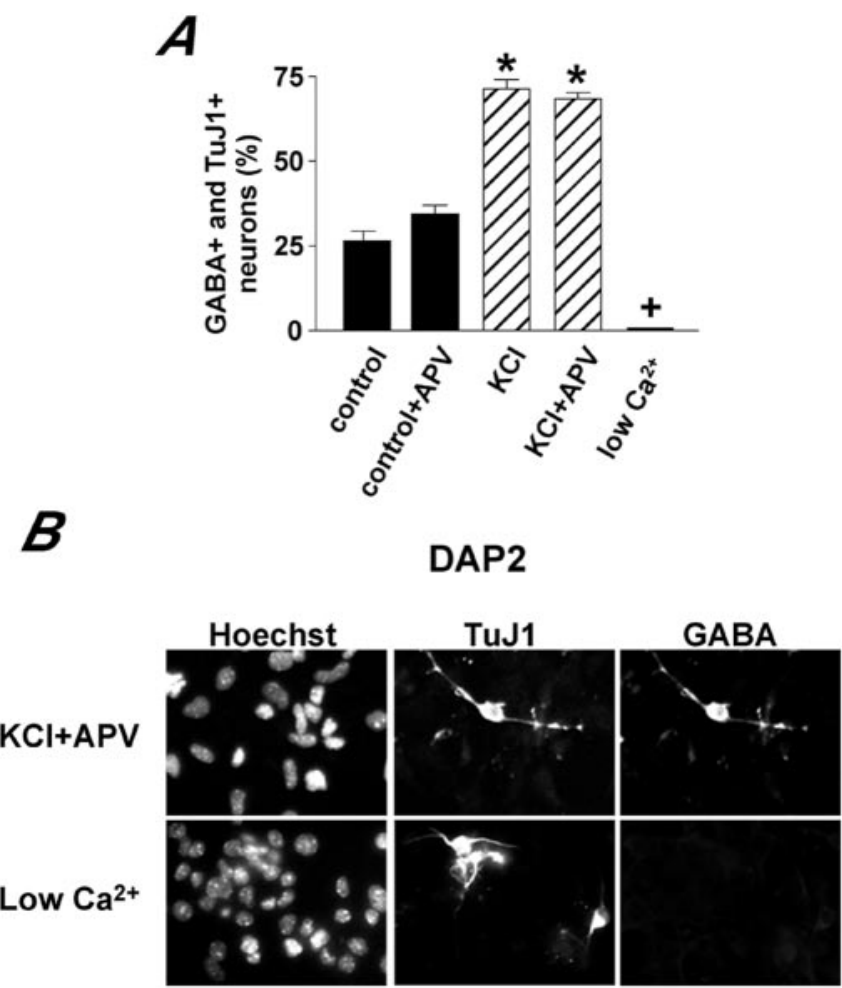

Figure 8. $\quad \mathrm{KCl}_{\text {and low }} \mathrm{Ca}^{2+}$ modulate $\mathrm{GABA}$ expression. $A$ shows a quantitative analysis of the number of TuJ1 and GABA double-immunopositive neurons found at DAP 2 in neurosphere cultures differentiating in the indicated conditions. The data represent mean \pm SEM of at least three independent experiments. ${ }^{*} p<0.001$, significantly different from control; ${ }^{+} p<0.05$, significantly different from control. $B$ shows examples of immunofluorescence recorded from cells treated as shown.

signals: low-frequency spikes control the development of GABA expression and higher-frequency growth cone-localized $\mathrm{Ca}^{2+}$ waves regulate neurite extension (Gu and Spitzer, 1995). Although our results do not allow a functional discrimination between different types of $\mathrm{Ca}^{2+}$ signals, they show that also in neurosphere-derived precursors, $\mathrm{Ca}^{2+}$ transients can be either localized to a specific cellular region or engulf the whole cell body. In addition to their subcellular location, localized and global signals found in neurosphere-derived precursors show differences in frequency and amplitude that parallel the differences observed between waves and spikes in Xenopus spinal cord neurons. Consistent with results obtained in amphibian spinal cord neurons, our analysis shows a positive correlation between GABA expression and frequency of spontaneous events.

One possible mechanism by which $\mathrm{Ca}^{2+}$ transients could affect GABA receptor expression is the promotion of gene transcription. Several lines of evidence support such a hypothesis. There is a correlation between $\mathrm{Ca}^{2+}$ signaling and the level of glutamic acid decarboxylase transcripts (Watt et al., 2000). In cerebellar granule cells, it has been suggested that $\mathrm{Ca}^{2+}$ ions entering through voltage-gated channels modulate expression of GABA receptor $\delta$ subunit through activation of CaM kinases (Gault and Siegel, 1997). We also found that the activation of voltage-gated channels by $\mathrm{KCl}$ was sufficient to promote GABA expression and that NMDA receptor activity was not required (Fig. 8).

Although our results concur with those from Xenopus spinal cord neurons in terms of a correlation between the frequency of $\mathrm{Ca}^{2+}$ signals and the acquisition of GABA expression, the effect 

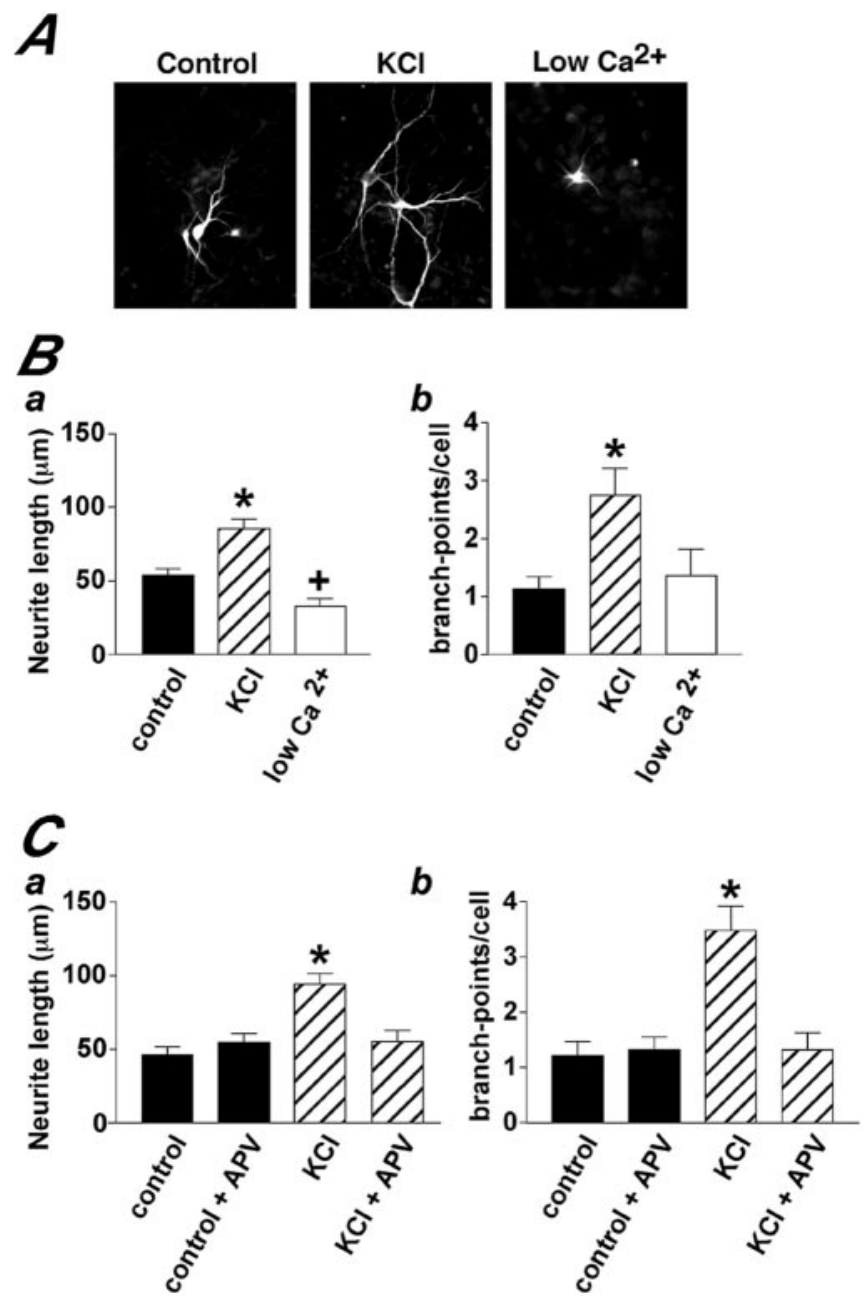

Figure 9. $\mathrm{KCl}$ and low $\mathrm{Ca}^{2+}$ modulate neuronal morphology. $A$ shows examples of TuJ1immunoreactive neurons found in cultures exposed for $24 \mathrm{hr}$ to $\mathrm{KCl}$, low $\mathrm{Ca}^{2+}$, or control conditions. ${ }^{*} p<0.01$, significantly different from control; ${ }^{+} p<0.05$, significantly different from control. $B$ shows a quantitative summary of the effects of $\mathrm{KCl}$ and low $\mathrm{Ca}^{2+}$ conditions on neurite length and branch points. Cillustrates the abolition of $\mathrm{KCl}$-induced changes in neuronal morphology by the NMDA receptor blocker APV. The data represent mean \pm SEM of at least three independent experiments.

of spontaneous $\mathrm{Ca}^{2+}$ signals on neurite length appears to be different. In our neurosphere-derived precursors, conditions that abolish $\mathrm{Ca}^{2+}$ signals (i.e., low $\mathrm{Ca}^{2+}$ medium) do not induce an increase in neurite length. Indeed, neurons from cultures exposed to low $\mathrm{Ca}^{2+}$ conditions exhibit shorter neurites than cells in control conditions (Fig. 9). Moreover, membrane depolarization, which increases the frequency of $\mathrm{Ca}^{2+}$ signals, increases neurite length and the number of branch points.

This different effect of $\mathrm{Ca}^{2+}$ in the two systems may be attributable to several factors other than cell type and species differences. In our experiments, neurons were grown on an astrocytic cell layer that may affect their morphology, for example, by releasing factors into the culture medium. Our results show that the NMDA receptor blocker APV decreases neurite length in $\mathrm{KCl}$ treated cultures but not in control conditions (Fig. 9), indicating that NMDA receptor-mediated neurite extension is operating in depolarizing conditions. It is plausible that $\mathrm{KCl}$ induced NMDA receptor activation by promoting the release of glutamate or growth factors into the medium (Blondel et al., 2000). It is also possible that the molecular machinery underlying neurite exten- sion varies during differentiation, and $\mathrm{Ca}^{2+}$ signals may have different effects depending on the particular stage of differentiation. Amphibian neurons exhibit a $\mathrm{Ca}^{2+}$-sensitive period during the $12 \mathrm{hr}$ after plating in which low $\mathrm{Ca}^{2+}$ conditions cause an increase in neurite length (Holliday et al., 1991). During this time frame, periodic $\mathrm{Ca}^{2+}$ elevations inhibit neurite extension by promoting calcineurin activation and affecting the phosphorylation state of cytoskeletal proteins (Lautermilch and Spitzer, 2000). Because in our system neurons were exposed to low $\mathrm{Ca}^{2+} 24 \mathrm{hr}$ after plating, it is possible that at this stage different mechanisms preside over neurite extension and are affected differently by $\mathrm{Ca}^{2+}$ signals. This suggestion is supported by the observation that the effect of membrane depolarization on neurite length was unaffected by inhibitors of calcineurin (our unpublished observations). Furthermore, it is not always easy to predict the consequence of a rise in $\mathrm{Ca}^{2+}$ levels on growth cone behavior. Large rises can cause growth cone collapse, whereas more modest signals can either slow or promote neurite outgrowth (Spitzer et al., 2000).

Besides affecting differentiation of neuronal cells, spontaneous $\mathrm{Ca}^{2+}$ signals may play a general role in the differentiation of other precursor cells. Indeed, spontaneous $\mathrm{Ca}^{2+}$ oscillations were observed in developing myocytes (Ferrari and Spitzer, 1999), non-neuronal neural crest cells (Carey and Matsumoto, 1999), and endodermal cells (Sauer et al., 1998), indicating that $\mathrm{Ca}^{2+}$ transients are a hallmark of developing precursors and not an exclusive property of differentiating neurons. Different types of $\mathrm{Ca}^{2+}$ signals are present at different stages of differentiation (Owens and Kriegstein, 1998; Owens et al., 2000), and the molecular machinery dictating $\mathrm{Ca}^{2+}$ homeostasis changes during neural precursor development (Maric et al., 2000). These observations suggest that $\mathrm{Ca}^{2+}$ transients may participate in different signaling events at different stages of development.

In summary, our data show that complex patterns of spontaneous $\mathrm{Ca}^{2+}$ signals can be recorded in differentiating neurosphere-derived precursor cells. Despite their heterogeneity, these events can be grouped loosely into local and global $\mathrm{Ca}^{2+}$ signals. These two types of $\mathrm{Ca}^{2+}$ signal appear to control different aspects of neuronal precursor development, with the NMDA receptor-dependent local $\mathrm{Ca}^{2+}$ signals primarily controlling neurite morphology and the global events regulating acquisition of neurotransmitter phenotype. Although such $\mathrm{Ca}^{2+}$ signals persist for many days, they become less frequent as the neurons mature. The $\mathrm{Ca}^{2+}$ signals in neuronal cells can be enhanced or inhibited by altering the culture conditions to promote or inhibit $\mathrm{Ca}^{2+}$ entry. Such modulation of $\mathrm{Ca}^{2+}$ signaling has significant effects on the acquisition of neurotransmitter phenotype and cellular morphology at early (i.e., DAP 2) and late (i.e., DAP 5) stages of neurosphere-derived precursor differentiation.

\section{References}

Berridge MJ, Bootman MD, Lipp P (1998) Calcium—a life and death signal. Nature 395:645-648.

Blondel O, Collin C, Mc Carran WJ, Zhu S, Zamostiano R, Gozes I, Brenneman DE, Mc Kay RDG (2000) A glia-derived signal regulating neuronal differentiation. J Neurosci 20:8012-8020.

Bootman MD, Lipp P, Berridge MJ (2001) The organisation and functions of local $\mathrm{Ca}^{2+}$ signals. J Cell Sci 114:2213-2222.

Carey MB, Matsumoto SG (1999) Spontaneous calcium transients are required for neuronal differentiation of murine neural crest. Dev Biol 215:289-313.

Cheng H, Lederer WJ, Cannell MB (1993) Calcium sparks elementary events underlying excitation-contraction coupling in heart muscle. Science 262:740-744.

Ciccolini F (2001) Identification of two distinct types of multipotent neural 
precursors that appear sequentially during CNS development. Mol Cell Neurosci 17:895-907.

Ciccolini F, Svendsen CN (1998) Fibroblast growth factor 2 (FGF-2) promotes acquisition of epidermal growth factor (EGF) responsiveness in mouse striatal precursor cells: identification of neural precursors responding to both EGF and FGF-2. J Neurosci 18:7869-7880.

Feller MB, Wellis DP, Stellwagen D, Werblin FS, Shatz CJ (1996) Requirement for cholinergic synaptic transmission in the propagation of spontaneous retinal waves. Science 272:1182-1187.

Ferrari MB, Spitzer NC (1999) Calcium signaling in the developing Xenopus myotome. Dev Biol 213:269-282.

Gault LM, Siegel RE (1997) Expression of the $\mathrm{GABA}_{\mathrm{A}}$ receptor $\delta$ subunit is selectively modulated by depolarization in cultured rat cerebellar granule neurons. J Neurosci 17:2391-2399.

Gomez TM, Spitzer NC (1999) In vivo regulation of axon extension and pathfinding by growth-cone calcium transients. Nature 397:350-355.

Gomez T, Snow DW, Letourneau PC (1995) Characterisation of spontaneous calcium transients in nerve growth cones and their effect on growth cone migration. Neuron 14:1233-1246.

Gritti A, Frolichsthal-Schoeller P, Galli R, Parati EA, Cova L, Pagano SF, Bjornson CR, Vescovi AL (1999) Epidermal and fibroblast growth factors behave as mitogenic regulators for a single multipotent stem cell-like population from the subventricular region of the adult mouse forebrain. J Neurosci 19:3287-3297.

Gu X, Spitzer NC (1995) Distinct aspects of neuronal differentiation encoded by frequency of spontaneous neuronal $\mathrm{Ca}^{2+}$ transients. Nature 375:784-787.

Gu X, Olson EC, Spitzer NC (1994) Spontaneous neuronal calcium spikes and waves during early differentiation. J Neurosci 14:6325-6335.

Holliday J, Adams RJ, Sejnowski TJ, Spitzer NC (1991) Calcium-induced release of calcium regulates differentiation of cultured spinal neurons. Neuron 7:787-796.

Komuro H, Rakic P (1996) Intracellular $\mathrm{Ca}^{2+}$ fluctuations modulate the rate of neuronal migration. Neuron 17:275-285.

Lautermilch NJ, Spitzer NC (2000) Regulation of calcineurin by growth cone calcium waves controls neurite extension. J Neurosci 20:315-325.

Lendahl U, Zimmerman LB, McKay RD (1990) CNS stem cells express a new class of intermediate filament protein. Cell 60:585-595.

Liljelund P, Netzeband JG, Gruol DL (2000) L-type calcium channels me- diate calcium oscillation in early postnatal Purkinje neurons. J Neurosci 20:7394-7403.

Maric D, Maric I, Barker JL (2000) Developmental changes in cell calcium homeostasis during neurogenesis of the embryonic rat cerebral cortex. Cereb Cortex 10:561-573.

McKay R (1997) Stem cells in the central nervous system. Science 276:66-71.

Owens DF, Kriegstein AR (1998) Patterns of intracellular calcium fluctuation in precursor cells of the neocortical ventricular zone. J Neurosci 18:5374-5388.

Owens DF, Flint AC, Dammermann RS, Kriegstein AR (2000) Calcium dynamics of neocortical ventricular zone cells. Dev Neurosci 22:25-33.

Reynolds BA, Weiss S (1992) Generation of neurons and astrocytes from isolated cells of the adult mammalian central nervous system. Science 255:1707-1710.

Reynolds BA, Weiss S (1996) Clonal and population analyses demonstrate that an EGF-responsive mammalian embryonic CNS precursor is a stem cell. Dev Biol 175:1-13.

Sauer H, Hofmann C, Waternberg M, Wobus AM, Hescheler J (1998) Spontaneous calcium oscillation in embryonic stem cell-derived primitive endodermal cells. Exp Cell Res 238:13-22.

Sorimachi M, Morita Y, Nakamura H (1990) Possible regulation of the cytosolic-free calcium concentration by $\mathrm{Na}+$ spikes in immature Purkinje cells. Neurosci Lett 111:333-338.

Spitzer NC, Lautermilch NJ, Smith RD, Gomez TM (2000) Coding of neuronal differentiation by calcium transients. BioEssays 22:811-817.

Svendsen CN, Smith AG (1999) New prospects for human stem-cell therapy in the nervous system. Trends Neurosci 22:357-364.

Thomas D, Tovey SC, Collins TJ, Bootman MD, Berridge MJ, Lipp P (2000) A comparison of fluorescent indicators and their use in measuring elementary and global $\mathrm{Ca}^{2+}$ signals. Cell Calcium 28:213-223.

Watt SD, Gu X, Smith RD, Spitzer NC (2000) Specific frequencies of spontaneous $\mathrm{Ca}^{2+}$ transients upregulate GAD 67 transcripts in embryonic spinal neurons. Mol Cell Neurosci 16:376-387.

Wong ROL, Chernjavsky A, Smith SJ, Shatz CJ (1995) Early functional neural networks in the developing retina. Nature 374:716-718.

Yuste R, Peinado A, Katz LC (1992) Neuronal domains in developing neocortex. Science 257:665-669. 